\title{
Estrogen Receptor Beta Inhibits the Proliferation, Migration, and Angiogenesis of Gastric Cancer Cells Through Inhibiting Nuclear Factor-Kappa B Signaling [Retraction]
}

\author{
Zhang Y, Wu Y, Zhou X, Yi B, Wang L. Onco Targets \\ Ther. 2019;12:9153-9164.
}

The Editor and Publisher of OncoTargets and Therapy wish to retract the published article.

We were notified of potential image manipulation in the published article. The issues relate to the alleged duplication of images shown in Figures 3B, 4B and 5A. Despite repeated attempts to contact the authors, they have not responded to our queries within the required timeframe.
The editor determined the findings of the study were no longer valid and requested for the article to be retracted.

Our decision-making was informed by our policy on publishing ethics and integrity and the COPE guidelines on retraction.

The retracted article will remain online to maintain the scholarly record, but it will be digitally watermarked on each page as "Retracted".

\section{Publish your work in this journal}

OncoTargets and Therapy is an international, peer-reviewed, open access journal focusing on the pathological basis of all cancers, potential targets for therapy and treatment protocols employed to improve the management of cancer patients. The journal also focuses on the impact of management programs and new therapeutic agents and protocols on patient perspectives such as quality of life adherence and satisfaction. The manuscript management system is completely online and includes a very quick and fair peer-review system, which is all easy to use. Visit http://www.dovepress.com/ testimonials.php to read real quotes from published authors. 